\title{
Expression of estrogen receptor $\beta 1$ in colorectal cancer: Correlation with clinicopathological variables
}

\author{
LEA RATH-WOLFSON $^{1}$, OFER PURIM ${ }^{2}$, EDWARD RAM ${ }^{3}$, \\ SARA MORGENSTERN $^{4}$, RUMELIA KOREN $^{1}$ and BARUCH BRENNER ${ }^{2}$ \\ ${ }^{1}$ Department of Pathology, Hasharon Hospital; ${ }^{2}$ Department of Oncology, Belinson Hospital; \\ ${ }^{3}$ Department of Surgery 'A', Hasharon Hospital; ${ }^{4}$ Department of Pathology, Belinson Hospital, \\ Rabin Medical Center, Petah Tikva, affiliated to Sackler Faculty of Medicine, Tel-Aviv University, Petah Tikva, Israel
}

Received November 1, 2011; Accepted January 20, 2012

DOI: $10.3892 /$ or.2012.1712

\begin{abstract}
Colorectal cancer (CRC) is a common malignancy in both genders with a high death rate, accounting for about 56,000 each year in the USA only. In this study we examined the differences in CRC between the genders. We also looked for differences in the staining of the tumors and adjacent colonic mucosa to estrogen receptor $\beta 1$ and its possible prognostic value. Fifty-five specimens from patients who underwent resection of colon cancer in our institute were sectioned and stained for estrogen receptor $\beta 1$. The histopathological slides were evaluated for positive staining in the tumor and the normal colonic mucosa as well. The results were statistically analyzed. Positive estrogen receptor $\beta 1$ stain was found in the nuclei of the tumor cells. We noted positive stain also in the cytoplasm of the tumor cells. Similar findings were observed in the normal colonic mucosa. Statistically significant differences were found regarding the positivity of the staining between the deceased and surviving patients, men/women and those who had metastases vs. the non-metastatic ones. Our data suggest that there is an estrogen influence on the development and progression of colon cancer. Furthermore, it was found to be higher in the more severe cases.
\end{abstract}

\section{Introduction}

Colorectal cancer (CRC) is a common malignancy in both genders (1). However, CRC shows several gender-related differences in incidence, response to chemotherapy and certain molecular characteristics. It has therefore been suggested that exposure to estrogen and/or estrogenic compounds may underlie these differences.

Correspondence to: Dr Lea Rath-Wolfson, Department of Pathology, Hasharon Hospital, POB 101, Petah Tikva, Israel

E-mail: leavo@clalit.org.il

Key words: colon cancer, estrogen receptor $\beta 1$ stain, gender, prognosis and survival
$\mathrm{CRC}$ is more common in men than women, the difference being more striking amongst premenopausal women and agematched men (1). The oncogenic effects of estrogens have been investigated extensively in breast cancer, where hormonereceptor modulators are an integral part of targeted therapy. Little is know about estrogen signalling in CRC.

Estrogens are steroid hormones, historically associated solely with the human female reproductive cycle. The nuclear receptor of estrogen was identified in rat uteri by Toft and Gorski in 1966 (2) and was later named estrogen receptor $\alpha$ $(\mathrm{ER} \alpha)$, after the discovery of the estrogen receptor $\beta(\mathrm{ER} \beta)$ in 1996 (3). It is a nuclear receptor for 17 $\beta$-estradiol, located on chromosome $6 \mathrm{q} 25$. Since the identification of two types of estrogen receptors, ER $\alpha$ and ER $\beta$, by Kuiper et al in 1996 (3), the effects of estrogen on various tissues have been investigated. Estrogen receptors (ER) were found to represent the major pathway via which estrogens and estrogenic compounds act.

$\mathrm{ER} \alpha$ and ER $\beta$ have different biological functions, as indicated by their specific expression patterns and the distinct phenotypes observed in ER $\alpha$ and $\mathrm{ER} \beta$ knockout ( $\alpha \mathrm{ERKO}$ and $\beta E R K O)$ mice. ER $\alpha$ and $E R \beta$ appear to have overlapping but also unique sets of downstream target genes, as judged from a set of microarray experiments. Thus, $\operatorname{ER} \alpha$ and $\operatorname{ER} \beta$ have different transcriptional activities in certain ligand, cell-type, and promoter contexts, which may help to explain some of the major differences in their tissue-specific biological actions (4).

It seems resonable, therefore, that attempts to explain gender differences in CRC should consider the two ER subtypes. ER $\alpha$ and ER $\beta$ have similar DNA-binding and ligand-binding, but otherwise there is little homology. ER $\beta$ is found on chromosome $14 \mathrm{q} 23.2$, and is about $61.2 \mathrm{~kb}$. The $\mathrm{ER} \beta$ protein is produced from eight exons. Additionally, there are two untranslated exons, $0 \mathrm{~N}$ and $0 \mathrm{~K}$, in the $5^{\prime}$ region and an exon at the $3^{\prime}$ end that can be spliced to exon 7 to produce the alternative ER $\beta$ isoform (4). It is known to have at least five isoforms, ER $\beta 1$ the wild-type, and other isoforms numbered 2-5 (5). The interior of the ligand-binding pocket is mostly conserved with the only difference in two contact residues. This explains the similar affinities of ER $\beta$ and ER $\alpha$ for endogenous estrogen. 
Estrogens are known to affect the growth, differentiation and function of target tissues (6). Enmark et al (7) showed high titers of ER $\beta$ mRNA in human colonic mucosal epithelium.

There are data suggesting that women are more likely to respond to 5-fluorouracil (5-FU) based chemotherapy than men (8). This may relate to a relationship between estrogens and cell proliferation, which in turn may determine sensitivity to chemotherapy (9). Most studies have failed to demonstrate substantial expression of ER $\alpha$ protein and/or mRNA amongst CRCs (10-12).

In this study we determined the clinico-pathological correlation of ER $\beta 1$ in CRC and whether there were gender differences, as it has not been reported in the literature.

\section{Materials and methods}

Patients and clinical data. The study included 55 patients with metastatic CRC, either at presentation or afterwards. The selection of patients with metastatic disease allowed the evaluation of the correlation between ER staining and the efficacy of first line treatment. The mean age of the entire study group was 68 years (range, 50-81 years). There were 29 males, with a mean age of 67.7 years (range, 52-78 years), and 26 females, with a mean age of 64.9 years (range, 51-77 years). All but one patient were Jews, mostly Sephardic $(51 \%)$ or Ashkenazi $(43 \%)$.

All patients underwent surgical resection of the tumor at the Rabin Medical Centre between 1996-2005. Forty-two of the tumors $(76 \%)$ were localized to the colon and 13 to the rectum. In the group of colon cancer 23 were males and 19 females, while in the rectal cancer group, 7 were males and 6 females. Seventeen operations were right hemicolectomy, 8 left hemicolectomy, 13 sigmoidectomy, 3 subtotal colectomy, one Hartman operation and one abdominoperineal resection. Most of the operations were open abdominal resections, while 12 were operated laparoscopically.

The histological diagnosis of all the tumors was adenocarcinoma. Eight (14\%) were well-differentiated adenocarcinoma (grade 1), 36 (65\%) were moderately-differentiated (grade 2) and $11(20 \%)$ were poorly-differentiated (grade 3 ).

In accordance with the inclusion criteria, $55 \%$ of the patients had metastatic disease already at presentation. The rest were diagnosed with stage II or III and developed metastases afterwards.

At the time of the analysis, 53 patients (96\%) had died of $\mathrm{CRC}$ and two (4\%) were alive. The median overall survival (OS) of the entire group from the diagnosis of metastatic disease was 21.41 months (range, 3.38-93.77 months). The median duration of follow-up was 2.5 years (range, $0.5-12.9$ years).

Postoperative treatment. All patients had metastatic disease, either at diagnosis or at the course of their disease. They all received the same standard first line treatment for metastatic CRC and the response of their disease to this treatment could be determined. The first line treatment was in all cases a standard combination of 5-FU, leucovorin (LV) and irinotecan, the FOLFIRI regimen.

Of the 25 patients who were diagnosed with localized disease, 17 (68\%) received postoperative adjuvant treatment, mainly standard 5-FU/LV.
The response rate to first line FOLFIRI regimen was $44 \%$ and the median progression-free survival (PFS) was 8.65 months (range, 1.63-61.63 months).

Pathological data. In order to evaluate the predictive impact of the ER $\beta 1$ and ER $\alpha$ expression in their primary tumor, patients were eligible for this study if they had adequate information on their primary tumor, which was also available for the receptor expression analysis and on their response to first line treatment for metastatic disease.

The histological slides from all cases were revised. From each case, histological slides, one representing the tumor and normal tissue were selected. The corresponding paraffin blocks were chosen. Serial 3-4 $\mu$ m-thick sections were cut and stained by haematoxylin and eosin (H\&E).

Immunohistochemical assay and image quantitation methods. Representative paraffin-embedded tissue from all tumors were immunohistochemically stained for ER $\beta 1$ and ER $\alpha$.

Sections, 3-4 $\mu$ m-thick, were cut and placed on super frost plus slides and then dried overnight at $37^{\circ} \mathrm{C}$. The slides were deparaffinized with 2 changes of xylene and rehydrated through a graded series of ethanol. They were washed in $100 \%$ etanol twice for $5 \mathrm{~min}$ and then etanol $95 \%$ for further $5 \mathrm{~min}$. Afterwards they were washed in distilled water for $1 \mathrm{~min}$. Endogenous peroxidase was blocked with $3 \%$ hydrogen peroxide for $10 \mathrm{~min}$ at room temperature and then rinsed twice in distilled water. For the antigen retrival we used the pressure cooker method with nuclear deckloaker buffer ( $\mathrm{pH} 9.5$ ). Sections were washed in distilled water and incubated with the primary antibody, ER $\beta 1$ monoclonal antibody (Serotec) diluted 1:10 for $1 \mathrm{~h}$, in room temperature. Another group of sections was stained with ER $\beta$, a monoclonal antibody (Novocastra) diluted 1:100 for $1 \mathrm{~h}$ at room temperature. Both procedures were followed by additional rinse with washing buffer (PBS) and incubation with a polymer detection kit (HRP broad spectrum Zymed) for 15 min at room temperature. Sections were stained with diaminobenzidine (DAB) solution for $10 \mathrm{~min}$ at room temperature and then rinsed with tap water for 2-5 min.

Sections were counterstained in Mayer's hematoxylin for $5 \mathrm{~min}$ and rinsed again with running tap water followed with dehydration through $95 \%$ ethanol for 1 min and $100 \%$ ethanol for $2 \mathrm{~min}$ followed by xylene for $2 \mathrm{~min}$ coverslip with mounting media. Each case was stained with a positive control, which was normal colonic mucosa.

In each case the tumor and normal mucosa were scanned at low and high magnification. To assess the level of tissue ER $\beta 1$ and ER $\alpha$ expression, the percentage of positively stained cells was registered and also the intensity of the stain in the nuclei and cytoplasm. The intensity was 1,2 or 3 in comparison with the control stain. The final score was the result of multiplication of the stain intensity with the percentage of positively stained cells.

Statistical analysis. The expression of ER $\beta 1$ in the cytoplasm and nuclei of the tumor and normal colon were compared with age, gender, CEA level, tumor grade, nodal status, presence of synchronous metastases and stage of disease at presentation. The expression was also compared with treatment and survival. 


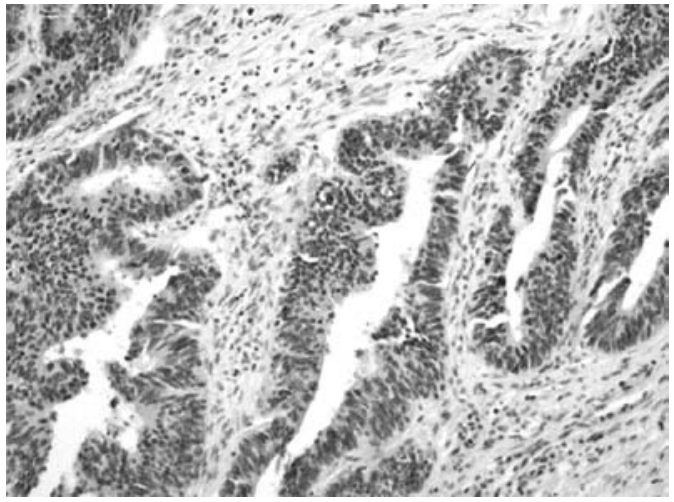

Figure 1. Positive ER $\beta 1$ stain in the nuclei of the tumor cells (original magnification, $\mathrm{x} 10)$.

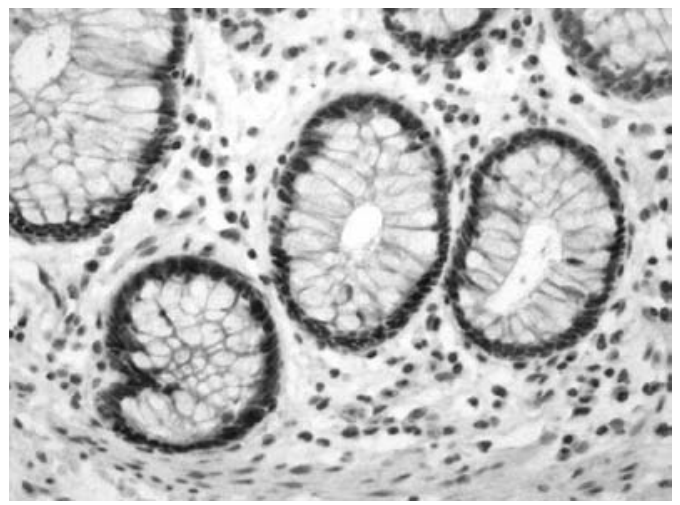

Figure 2. Positive ER $\beta 1$ stain in the nuclei of the normal cells (original magnification, $\mathrm{x} 10)$.

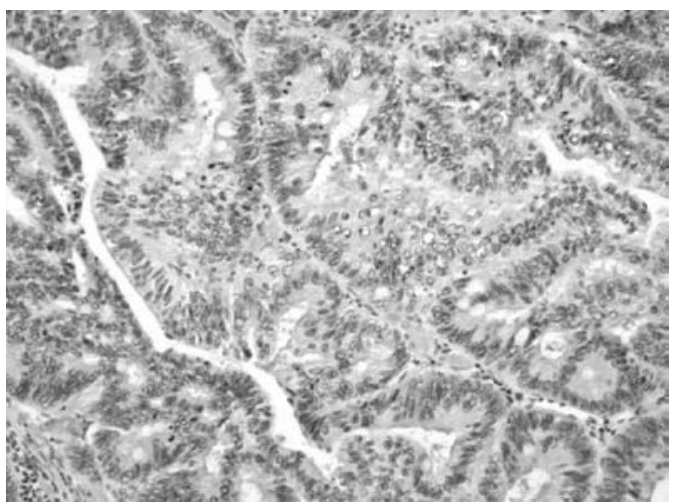

Figure 3. Positive ER $\beta 1$ stain in the cytoplasm of the tumor cells (original magnification, x10).

In order to examine these parameters, the ANOVA statistical analysis, t-test, Spearman's correlation and the Pearson correlation, were used. The study was approved by the IRB.

\section{Results}

We found positive ERß1 stain in the tumor tissue. The positive staining was seen in the nuclei of these cells (Fig. 1). In the nuclei of the normal cells we found positive ER $\beta 1$ staining as

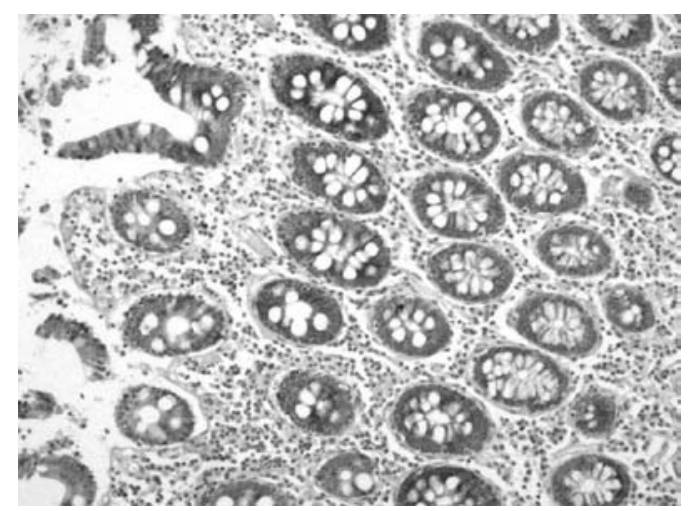

Figure 4. Positive ER $\beta 1$ stain in the cytoplasm of the normal colonic mucosal cells.

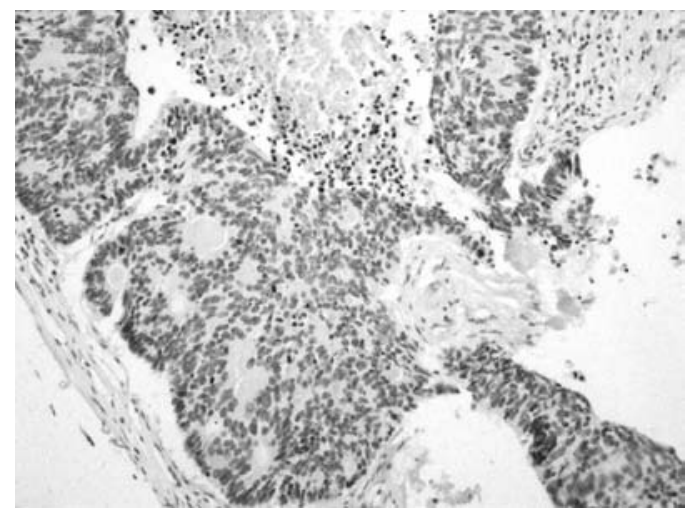

Figure 5. Negative ER $\beta 1$ stain in both nuclei and cytoplasm of tumor cells.

Nuclear stain ER $\beta 1$ in tumor cells

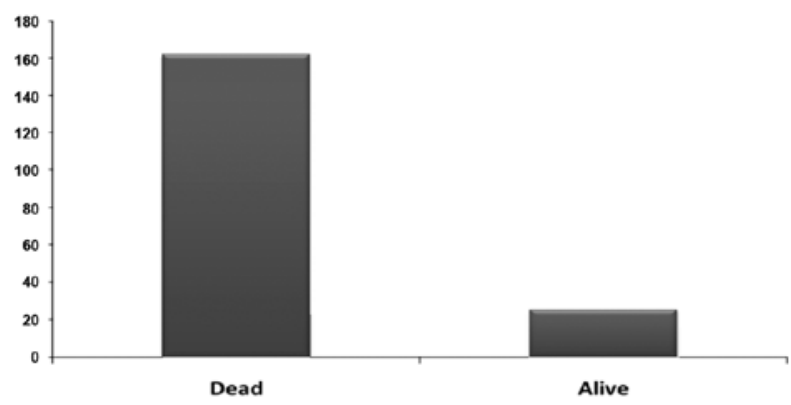

Figure 6. Nuclear stain of ER $\beta 1$ in tumor cells and the patient outcome.

well (Fig. 2). We also noted positive stain in the cytoplasm of both tumor (Fig. 3) and normal cells (Fig. 4). There were some cases with either negative nuclear or cytoplasmic stain as well as complete negative stain (Fig. 5). ER $\alpha$ was negative in both the tumor and normal tissues.

Expression of ER $\beta$ stain in the nuclei of the tumor cells. Those patients who were dead at the end of this study had a much higher nuclear ER $\beta 1$ positive stain in their tumor cells $(\mathrm{M}=164.60, \mathrm{Sd}=100.13)$ compared with patients who were still alive $(M=52.00, S d=38.99)$. The comparison between the two groups resulted in a highly significant difference $\left[\mathrm{t}_{(53)}=2.48\right.$, $\mathrm{P}<0.05]$ (Fig. 6). 


\section{Nuclear stain ER $\beta 1$ in tumor cells} (males)

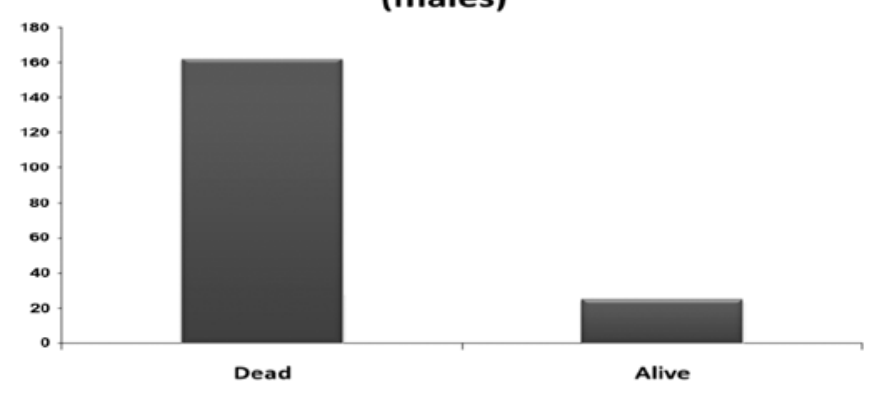

Figure 7. Nuclear stain of ER $\beta 1$ in tumor cells in males and the patient outcome.

\section{Nuclear stain of ER B1 in tumor and normal cells, among males}

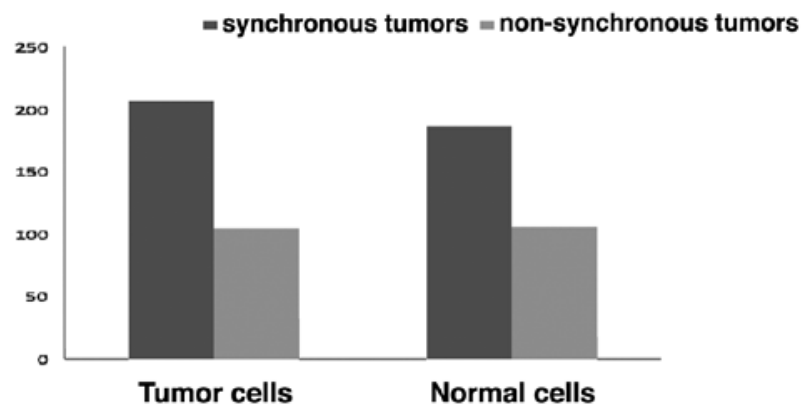

Figure 8. Nuclear stain of ER $\beta 1$ in tumor cells and normal cells in male patients with synchronous metastases.

When the staining of ER $\beta 1$ in the nuclei of the tumor cells of the dead male patients $(\mathrm{M}=162.96, \mathrm{Sd}=98.11)$ was compared with the nuclear staining of the male patients who were still alive $(M=25.00, S d=35.35)$, a marginal difference $\left[t_{(27)}=1.95\right.$, $\mathrm{P}=0.062]$ was found (Fig. 7).

At the time of the diagnosis, some patients had synchronous metastases. The nuclear stain of ER $\beta 1$ in the tumor cells of the patients who had synchronous metastases ( $M=196.21$, $\mathrm{Sd}=100.97$ ) was higher than those patients with no synchronous metastases $(\mathrm{M}=111.40, \mathrm{Sd}=83.32)$ and this difference was significant $\left[t_{(52)}=-3.33, P<0.005\right]$ (Fig. 8). Similarly, the expression of ER $\beta 1$ stain in the nuclei of the tumor cells of male patients with synchronous metastases $(\mathrm{M}=195.33, \mathrm{Sd}=101.60)$ was higher than male patients without metastases $(\mathrm{M}=108.57, \mathrm{Sd}=82.24)$, and the difference was significant $\left[\mathrm{t}_{(27)}=2.52, \mathrm{P}<0.05\right]$.

Those patients who did not have peritoneal metastases had a higher rate of nuclear ER $\beta 1$ stain in the tumor cells $(\mathrm{M}=186.90, \mathrm{Sd}=100.39)$ compared with patients who had peritoneal metastases had $(M=92.22, S d=53.51)$, and the difference was not significant. Among males, there was a significant difference between peritoneal metastases and nonperitoneal metastases in the nuclear ER $\beta 1$ stain in the tumor cells $\left[\mathrm{t}_{(28)}=2.65, \mathrm{P}<0.05\right]$.

Among females, there was a strong positive correlation between CEA and nuclear ER $\beta 1$ stain in the tumor cells $(r=0.41, \mathrm{P}<0.05)$. As CEA increased, an increase in the nuclear ER $\beta 1$ was seen, and vice versa.

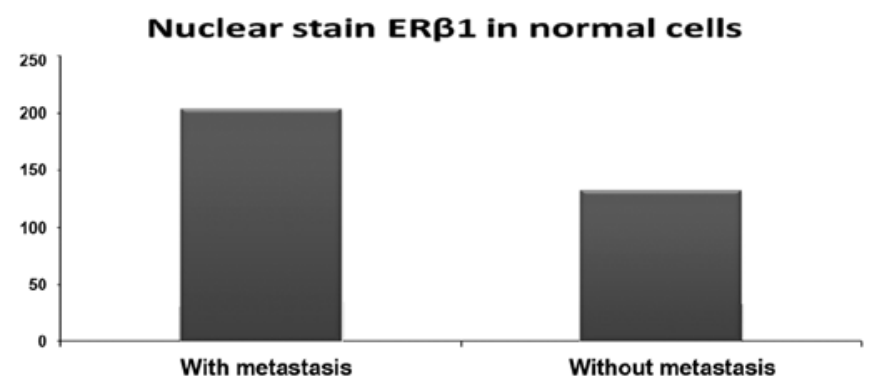

Figure 9. Nuclear stain of ER $\beta 1$ in normal cells and presence of synchronous metastasis.

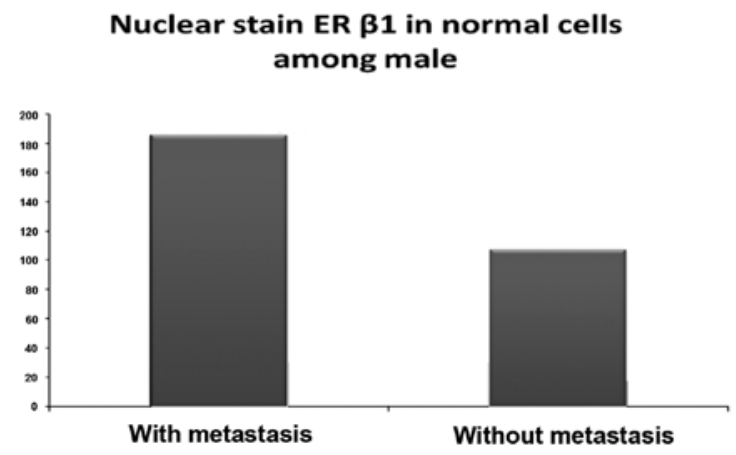

Figure 10. Nuclear stain of ER $\beta 1$ in normal cells in male patients and presence of synchronous metastases.

Expression of ER $\beta 1$ stain in the nuclei of the normal cells. We found a significant, medium and positive correlation between the patient nodal status and the nuclear ER $\beta 1$ stain in the normal cells $(\mathrm{r}=0.30, \mathrm{P}<0.05)$. As the node stage was higher, the nuclear stain of ER $\beta 1$ in normal cell nuclei was higher as well, and vice versa.

Patients with synchronous metastases had a higher rate of nuclear ER $\beta 1$ stain in the normal cells $(\mathrm{M}=203.21, \mathrm{Sd}=104.56)$ compared with those without metastases ( $\mathrm{M}=131.85, \mathrm{Sd}=100.46)$. The difference between the groups was significant $\left[\mathrm{t}_{(53)}=2.58\right.$, $\mathrm{P}<0.05$ ] (Fig. 9).

When the comparison was limited to male patients, male patients with synchronous metastases had a higher rate of ER $\beta 1$ nuclear stain in the normal cells $(\mathrm{M}=185.33, \mathrm{Sd}=114.00)$ compared with those without such metastases $(M=107.14$, $\mathrm{Sd}=96.27$ ), but the difference reached only marginal significance $\left[\mathrm{t}_{(27)}=1.99, \mathrm{P}=0.057\right]$ (Fig. 10).

Those patients with synchronous metastases had higher rate of nuclear stain ER $\beta 1$ in nuclei of the normal cells $(\mathrm{M}=198.50, \mathrm{Sd}=104.08)$ than those with non-synchronous tumors $(M=116.20, S d=100.35)$, with a statistically significant difference $\left[\mathrm{t}_{(53)}=-2.97, \mathrm{P}<0.005\right]$.

The female patients who had died at the time of the analysis had a higher nuclear rate of ER $\beta 1$ stain in normal cells $(\mathrm{M}=205.65, \mathrm{Sd}=95.96)$ than female patients who were still alive at that time $(\mathrm{M}=80.00, \mathrm{Sd}=70.00)$ with a statistically significant difference $\left[\mathrm{t}_{(24)}=2.18, \mathrm{p}<0.05\right]$ (Fig. 11).

Expression of ERß1 staining the cytoplasm of the tumor cells. The female patients had higher cytoplasmatic ER $\beta 1$ in the tumor cells $(M=84.62, S d=62.94)$ than the male patients 


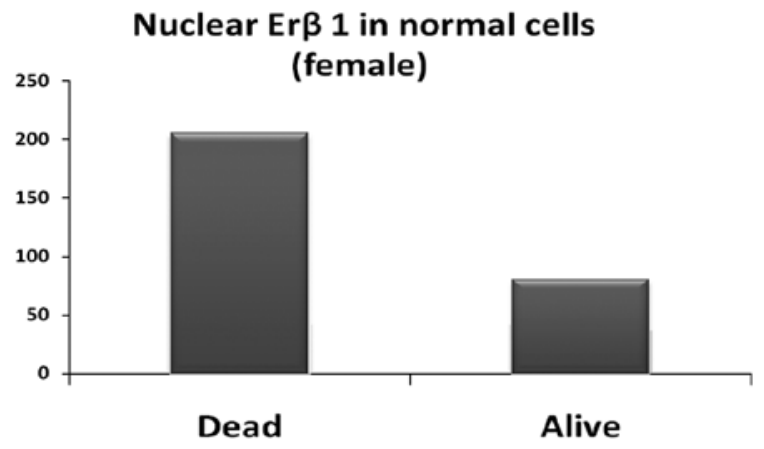

Figure 11. Nuclear stain of ER $\beta 1$ in normal cells in females and patient the outcome.

Cytoplasmatic ERB1 in tumor cells

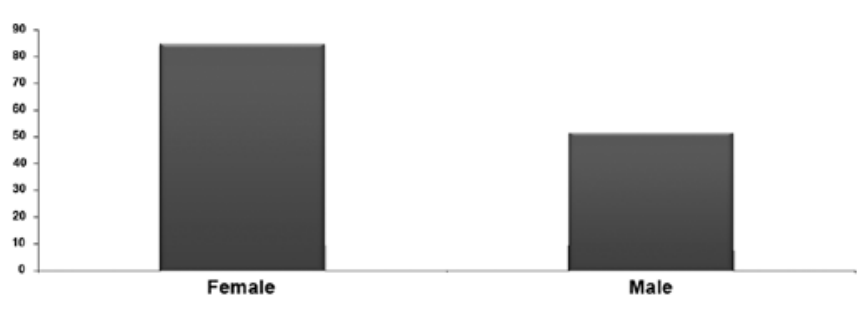

Figure 12. Cytoplasmatic stain of ER $\beta 1$ in tumor cells and gender.

$(\mathrm{M}=51.38, \mathrm{Sd}=52.22)$ and the difference was statistically significant $\left[\mathrm{t}_{(53)}=2.14, \mathrm{P}<0.05\right]$ (Fig. 12).

Among male patients there was a significant, strong and negative correlation between stage of the disease and cytoplasmatic ER $\beta 1$ in tumor cells $(r=-0.40, P<0.05)$, so that as the stage of the disease was higher, the cytoplasmatic ER $\beta 1$ in the tumor cells was less, and vice versa.

Expression of ER $\beta 1$ staining in the cytoplasm of normal cells. There was also a strong positive correlation between CEA and cytoplasmatic ER $\beta 1$ in normal cells $(r=0.56, \mathrm{P}<0.005)$. As CEA increased so did the cytoplasmatic ER $\beta 1$ in normal cells, and vice versa.

A general comparison of the immunohistochemical stain positivity in the tumor and normal cells showed no statistically significant correlations between the ER $\beta 1$ staining and patient age, tumor grade and response to treatment.

\section{Discussion}

Our study demonstrated that the ER $\beta 1$ expression in the nuclei of the tumor cells was significantly higher in colon carcinoma cases of those patients who died of the disease and especially in male patients. Higher expression was found also in the synchronous and metastatic patients. Among the female patients we found strong positive correlation with CEA.

Interestingly, we found also correlation with the expression of ER $\beta 1$ in the nuclei of the normal cells. Those cases with lymph nodes metastases and distant metastases at presentation had higher expression of ER $\beta 1$ and especially in the male patients. Statistically significant expression was found in the shynchronous cases, similar to those found in the nuclei of the tumor cells. The deceased female patients had higher ER $\beta 1$ expression in the nuclei of the normal cells.

We observed also positive ER $\beta 1$ staining in the cytoplasm of both tumor and normal cells. Female patients had higher expression of the ER $\beta 1$ in the cytoplasm of the tumor cells than male patients. Among the male patients there was a negative correlation with the stage of the disease, as the stage of the disease was higher the expression of ER $\beta 1$ was lower. There was also a positive correlation of the expression of ER $\beta 1$ in the cytoplasm of the normal cells and CEA levels.

In our study there was no correlation between the expression of ER $\beta 1$ and the therapy. The cause of gender differences in the epidemiology, natural history and therapy in colorectal cancer have not been investigated in depth.

Female prevalence is known in cases of gallstone disease and billiary cirrhosis, the cause of these differences is not known (13-16).

Recently Shmuely et al (17) demonstrated a gender difference in the eradication of Helicobacter pylori. The female response to therapy was better when compared to the male response.

Colorectal cancer is quite widespread. About 1 million cases of colorectal cancer are diagnosed every year around the world and half a million die of the disease every year. In the USA men have been shown to have higher risk of developing polyps while women are more prone to develop pure right sided polyps and tumors.

Soderlund $e t$ al also showed gender differences in the incidence of colorectal cancer in patients with inflammatory bowel disease. The female population showed a lower risk in these cases than the males (18).

CRC occurring in long-standing IBD and survival in patients with metastatic CRC was better in younger women than men (19). These differences disappeared after the age of 45 , suggesting that estrogen may be protective. Then it was found that hormone replacement therapy protected against $\mathrm{CRC}$ and decreased the incidence in $66 \%$ of patients after 15 years of therapy (20).

These data support the suggestion that there is an estrogen influence on the development and progression of these tumors. There is abundant ER $\beta 1$ expression in the normal colonic mucosa with decline in the colorectal cancer cells (21).

In our study the expression of ER $\beta 1$ showed no correlation with the tumor grade. It was higher in the more severe cases, those which presented with either metastases or died of the disease. Only in male patients, in the cytoplasm of the tumor cells, there was a negative correlation of the expression of ER $\beta 1$ with the stage of the disease.

\section{References}

1. DeCosse JJ, Ngoi SS, Jacobson JS and Cennerazzo WJ: Gender and colorectal cancer. Eur J Cancer Prev 2: 105-115, 1993.

2. Toft D and Gorski J: A receptor molecule for estrogens: isolation from the rat uterus and preliminary characteristics. Proc Natl Acad Sci USA 55: 1574-1581, 1966.

3. Kuiper GG, Enmark E, Pelto-Huikko M, Nilsson S and Gustafsson JA: Cloning of a novel receptor expressed in rat prostate and ovary. Proc Natl Acad Sci USA 93: 5925-5930, 1996.

4. Zhao C, Dahlman-Wright K and Gustafsson JA: Estrogen receptor $\beta$ : an overview and update. Nucl Recept Signal 6: e003, 2008. 
5. Moore JT, McKee DD, Slent-Kesler K, et al: Cloning and characterization of human estrogen receptor beta isoforms. Biochem Biophys Res Commun 247: 75-78, 1998.

6. Dobrazyka KM, Townson SM, Jiang S and Oesterreich S: Estrogen receptor corepressors - a role in human breast cancer? Endoc Relat Cancer 10: 517-536, 2003.

7. Enmark E, Pelto-Huikko M, Grandien K, et al: Human estrogen receptor beta-gene structure, chromosomal localization, and expression pattern. J Clin Endocrinol Metab 82: 4258-4265, 1997.

8. Elsaleh H, Joseph D, Grieu F, Zeps N, Spry N and Iacopetta B: Association of tumour site and sex with survival benefit from adjuvant chemotherapy in colorectal cancer. Lancet $355:$ 1745-1750, 2000.

9. Ravaioli A, Bagli L, Zucchini A and Monti F: Prognosis and prediction of response in breast cancer: the current role of the main biological markers. Cell Prolif 31: 113-126, 1998.

10. Slattery ML, Samowitz WS and Holden JA: Estrogen and progesterone receptors in colon tumors. Am J Clin Pathol 113: 364-368, 2000.

11. Dawson PM, Shousha S, Blair SD, et al: Oestrogen receptors in colorectal carcinoma. J Clin Pathol 43: 149-151, 1990.

12. Cameron BL, Butler JA, Rutgers J, Vargas HI, Purtell M and Sheppard B: Immunohistochemical determination of the estrogen receptor content of gastrointestinal adenocarcinomas. Am Surg 58: 758-760, 1992.

13. Browning JD and Sreenarasimhaiah J: Gallstone disease. In Sleisenger and Fordtran's Gastrointestinal and Liver Disease. 8th edition. Feldman M, Friedman LS and Brandt LS (eds). Saunders Elsevier, Philadelphia, pp1387-1418, 2006.
14. Angulo P and Lindor KD: Primary billiary cirrhosis. In: Sleisenger and Fordtran's Gastrointestinal and Liver Disease. 8th edition. Feldman M, Friedman LS and Brandt LS (eds). Saunders Elsevier, Philadelphia, pp1885-1898, 2006.

15. Richter JE: Gastroesophageal reflux disease and its complication. In: Sleisenger and Fordtran's Gastrointestinal and Liver Disease. 8th edition. Feldman M, Friedman LS and Brandt LS (eds). Saunders Elsevier, Philadelphia, pp905-936, 2006.

16. Tung BY and Kowdley KV: Sclerosing cholangitis and recurrent pyogenic cholangitis. In: Sleisenger and Fordtran's Gastrointestinal and Liver Disease. 8th edition. Feldman M, Friedman LS and Brandt LS (eds). Saunders Elsevier, Philadelphia, pp1461-1476, 2006.

17. Shmuely H, Yahav J, Samra Z, et al: Effect of cranberry juice on eradication of Helicobacter pylori in patients treated with antibiotics and a proton pump inhibitor. Mol Nutr Food Res 51: 746-771, 2007.

18. Soderlund S, Granath F, Brostrom O, et al: Inflammatory bowel disease confers a lower risk of colorectal cancer to females than to males. Gastroenterology 138: 1697-1703, 2010.

19. Hendifar A, Yang D, Lenz F, et al: Gender disparities in metastatic colorectal cancer survival. Clin Cancer Res 15: 6391-6397, 2009.

20. Long MD, Martin CF, Galanko JA and Sandler RS: Hormone replacement therapy, oral contraceptive use, and distal large bowel cancer: a population based case-control study. Am J Gastroenterol 105: 1843-1850, 2010.

21. Konstantinopoulos PA, Kominea A, Vandoros G, et al: Oestrogen receptor beta (ERbeta) is abundantly expressed in normal colonic mucosa, but declines in colon adenocarcinoma paralleling the tumour's dedifferentiation. Eur J Cancer 39: 1251-1258, 2003. 